\title{
MOVEMENTS AND CAPTURE-RECAPTURE DATA ANALYSIS OF THE VESPER RAT (NYCTOMYS SUMICHRASTI : RODENTIA, MURIDAE) IN A TROPICAL FOREST IN NORTHEASTERN OAXACA, MEXICO
}

\author{
Martín PÉrez-LuSTRe and Antonio SANTOS-Moreno \\ Laboratorio de Ecología Animal. Centro Interdisciplinario de Investigación para el Desarrollo Integral \\ Regional, Unidad Oaxaca, Instituto Politécnico Nacional. Hornos 1003, Santa Cruz Xoxocotlán, \\ Oaxaca. Codigo Postal 71230, MÉXICO. E-mail: asantosm90@hotmail.com \\ Correspondent author: Antonio Santos-Moreno. E-mail: asantosm90@hotmail.com
}

Pérez-Lustre, M. \& A. Santos-Moreno. 2010. Movements and capture-recapture data analysis of the vesper rat (Nyctomys sumichrasti: Rodentia, Muridae) in a tropical forest in northeastern Oaxaca, Mexico. Acta Zool. Mex. (n. s.), 26(3): 627-638.

ABSTRACT. In order to explain the population demography of the Vesper Rat (Nyctomys sumichrasti) and with regarding to an estimate of population size and survival rates, as well as possible differences in the movements distances between males and females, we analyzed capture-recapture data of this species from a trapping effort of 455 trap-nights and a total of 157 captures of 36 individuals which were livetraped at 3 trap heights: 3-9 m above ground (low canopy), 9-15 m (medium canopy) and the highest part of the canopy, 15-21.5 m. Due to differences between age categories in sample size, the analysis of capture-recapture histories was restricted to adult individuals. The sample of 29 adult individuals included 12 females ( 8 singletons and 4 captured in the complete study) and 17 males ( 5 singletons and 12 captured in the complete study); which represents a sex-ratio of $1: 1.41$, which did not differ statistically from 1:1. The capture-recapture histories were analyzed using the Cormack-Jolly-Seber model, where the best model maintains the survival constant and equal between sexes, and capture probability is constant through time, but differs between sexes. The survival probability was 0.8287 , while the capture probability was 0.874 for males and 0.5733 for females. Estimated population size included 19 males and 21 females. The average distance travelled by females was $34.86 \mathrm{~m}$ (standard deviation 5.92) with extreme values of 20.1 to 60.32, whereas for males was $35.42 \mathrm{~m}$ (standard deviation 18.27), with extreme values of 10.3 to $75.1 \mathrm{~m}$.

Key words: canopy; population size; small rodents; traveled distances; tropical forest.

Pérez-Lustre, M. \& A. Santos-Moreno. 2010. Análisis de datos de movimiento y de captura-recaptura de la rata arborícola (Nyctomys sumichrasti: Rodentia, Muridae) en una selva tropical del noreste de Oaxaca, México. Acta Zool. Mex. (n. s.), 26(3): 627-638.

RESUMEN. Con la finalidad de conocer algunos parámetros demográficos como el tamaño de población y las tasas de supervivencia de la rata arborícola Nyctomys sumichrasti, así como la estimación de distancias recorridas y sus diferencias entre machos y hembras, se analizaron los datos de

Recibido: 27/01/2010; aceptado: 11/06/2010. 
captura-recaptura de esta especie obtenidos con un esfuerzo de captura de 455 trampas-noches y un total de 157 capturas de 36 ejemplares. Las capturas se realizaron a tres niveles de altitud sobre los árboles: 3-9 m sobre el suelo (dosel bajo), 9-15 m (dosel medio) y la parte más alta del dosel, 15-21.5 m. Debido a las diferencias entre las categorías de edad en el tamaño de la muestra, el análisis de las historias de captura-recaptura se restringió a los individuos adultos. La muestra de 29 individuos adultos, incluyó 12 hembras (8 registradas solo en una ocasión y 4 capturadas en todos los muestreos) y 17 machos (5 registrados en un solo muestreo y 12 capturados en todos los muestreos), lo que representa una relación de sexos de 1:1.41, que no difiere estadísticamente de 1:1. Las historias de captura-recaptura se analizaron mediante el modelo probabilístico de Cormack-Jolly-Seber, donde el mejor modelo fue aquel en que la probabilidad de supervivencia aparente es igual entre sexos y constante a través del tiempo (0.8287) y la probabilidad de captura es constante a través del tiempo, pero difiere entre los sexos: 0.874 para los machos y 0.5733 para las hembras. El tamaño de la población se estimó en 19 machos y 21hembras. La distancia media recorrida por las hembras fue de 34.86 m (desviación estándar 5.92) con valores extremos de 20.1 a 60.32, mientras que para los machos fue de 35.42 m (desviación estándar 18.27), con valores extremos de 10.3 a $75.1 \mathrm{~m}$.

Palabras clave: Dosel; tamaño poblacional; pequeños roedores; distancias recorridas; bosque tropical.

\section{INTRODUCTION}

Canopy mammals include not only a few of the most charismatic and visible mammals of the world, as the most of the members of the order primates, but also some of the less known animals on planet, as many of small mammals belonging to tropics, this generally due to their nocturnal and secretive habits (Malcolm 2004). Furthermore there is a scarcity of safety techniques to sample habitats such as the canopy. Thus, tree-dwelling and semi-tree-dwelling small mammals have been poorly studied, and research has been usually limited to inventories (Woodman et al. 1995).

In Mexico, studies on tree-dwelling and semi-tree-dwelling small mammals are scarce, being practically exclusives of a deciduous forest at Chamela Biological Station (Estación Biológica de Chamela) in the state of Jalisco. Furthermore these studies show a lack of information about the species, for example a study in this station is limited to affirm that five of the seven species comprising the community are either tree-dwelling or semi-tree-dwelling (Ceballos 1990). Another study showed that from the six native rodent species documented in the area, two were captured exclusively in trees (Collet et al. 1975).

One of the tree-dwelling species of rat commonly found in the tropical and subtropical forests of the Americas is the Vesper Rat Nyctomys sumichrasti (Saussure 1860); which is endemic to Central America and is found from the southern part of the Mexican states of Jalisco and Veracruz, through central Panama, excluding the Yucatan Peninsula (Musser \& Carleton 2005). Its genus is monotypic and nine subspecies have been recognized (Hall 1981). Of these, four are present in Mexico, two of which have been recorded in the state of Oaxaca: N. s. pallidulus, which inhabits the southern mountainside forests of Isthmus of Tehuantepec, and N. s. sumichrasti, 
which inhabits humid environments in the northern portion of the state (Goodwin 1969). This species is strictly nocturnal (Peña et al. 2005), and uses intermediate and upper levels of forest and jungle; thus, it is usually found above $3 \mathrm{~m}$ and only rarely descend to the ground (Disney 1968, Emmons 1999). These habits probably explain the scarcity of samples of this species in scientific collections, even in zoologically well known regions (Anthony 1932). Hence, biological data have been derived from incidental observations (Goodwin 1934, Sánchez-Hernández et al. 1999, Timm \& Vriesendorp 2003), and the knowledge of its reproductive patterns has been derived from relevant observations in captivity (Birkenholtz \& Wirtz 1965). Thus, in this study we present some demographic parameters and patterns of movement of Nyctomys sumichrasti in a tropical forest in the region known as the Sierra Norte of Oaxaca in the southeastern of Mexico.

\section{MATERIAL AND METHODS}

Study area. The study was carried out at the site known as El Mameyal $\left(17^{\circ} 40^{\prime} 31.4^{\prime \prime} \mathrm{N}, 96^{\circ} 19^{\prime} 25.1^{\prime \prime} \mathrm{W}\right.$, mean altitude $1042 \mathrm{~m}$ a.s.l., Figure 1) in the municipality of Santiago Comaltepec, district of Ixtlán de Juárez, in the region known as the Sierra Norte, in the northern portion of the southeastern Mexican state of Oaxaca. The predominant vegetation is tropical and sub-tropical forest with shrubbery being the secondary vegetation (SEMARNAT, INEGI \& UNAM 2000), predominantly from the following families: Araceae, Asteraceae, Cecropiaceae, Fabaceae, Lauraceae, Piperaceae, and Moraceae (Boyle 1996). The dry season is from December to May, with an average precipitation of $225.53 \mathrm{~mm}(\mathrm{SD}=56.34)$ and an average temperature of $16.66^{\circ} \mathrm{C}(\mathrm{SD}=1.90)$. The rainy season is from June to November, with an average month precipitation of $670.87 \mathrm{~mm}(\mathrm{SD}=110.14)$ and an average temperature of $17.07^{\circ} \mathrm{C}(\mathrm{SD}=0.82)$ (García García 2007).

Field data. Sampling was carried out five nights per month from January to July 2007. Thirteen Sherman folding traps ( $3 \times 3.5 \times 9$ ") baited with a mixture of oat flakes and vanilla were set in thirteen trees of a 300 meters long lineal transect, where the separation for eleven trees was 18 meters approximately between them, and 50 meters for the last two due to the conditions resulting of logging. Throughout the study one trap was set in each tree, and depending of tree characteristics these were placed at different heights: 3-9 m above ground (low canopy), 9-15 m (medium canopy) and the highest part of the canopy, 15-21.5 m. Trees were selected that had branches connected to other trees, thus allowing the assumption of greater animal traffic due to the higher number of available routes; additionally, selected trees had certain characteristics that would allow the climbing such as branches that were sufficiently free of lianas and leaves. In order to climb the trees the single-rope technique was employed. 


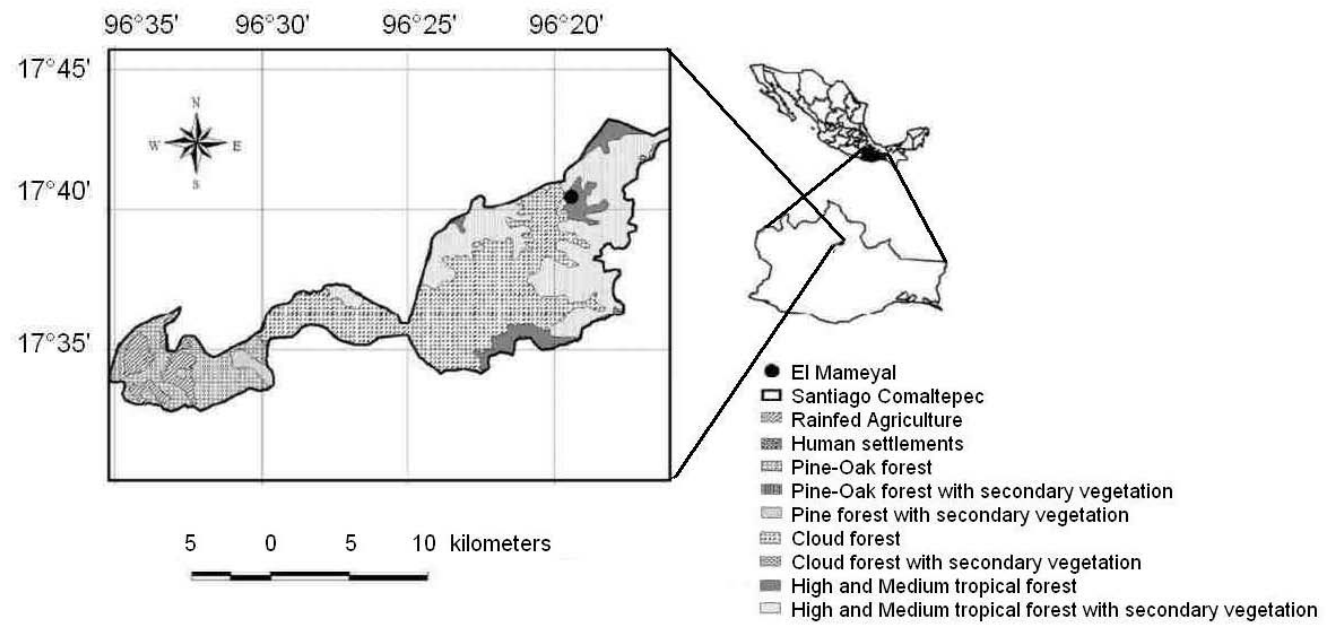

Figure 1. Geographic location of El Mameyal and main vegetation types of the municipality of Santiago Comaltepec, Oaxaca, Mexico.

The following information was recorded for each specimen captured for the first time: the trap and its location (i.e., transect position and height within the tree); sex; reproductive status (The male were considered active if they possessed descended testicles. The female were considered active if they were either pregnant or lactating, or if they had no hair in the periphery of their nipples), age (juveniles being small with thick, short hair, dark in color, with no evidence of reproductive activity, and adults being large with a vibrant dorsal color, long hair, or evidence of reproductive activity). Each specimen was ear-tagged with a numbered tag type 1005-1 (National Band \& Tag Co., USA), and immediately released at the capture site.

Data analysis. The capture-recapture histories were analyzed using the probabilistic Cormack-Jolly-Seber (CJS) model (Cormack 1964, Jolly 1965, Seber 1965, 1982, 1986) which includes two parameters: probability of survival $(\phi)$ and probability of capture (p), each of which may remain constant or vary either through time (measured as sample periods), or by sex; thus, considering all these possibilities, sixteen models can be constructed (Table 1). The construction of the models and the estimations of parameter values were carried out using MARK 4.0 (Cooch \& White 2002) with the nomenclature proposed by Lebreton et al. (1992). The selection of the best model was based on a Quasi-likelihood Akaike Information Criterion (QAICc) (Burnham \& Anderson 2002). The capture-recapture histories may be affected by other factors besides the probability of survival and capture (extra-binomial variation); thus, the parameters of all the models were adjusted dividing the deviance 
of each model (degree of discrepancy between the model and the data) by the average deviance of a simulation with 1000 replications. These replications are carried out so that the only sources of variance are those included in the model (parametric bootstrap, Manly 1997).

The CJS model assumes that the presence of transitory specimens (i.e., those passing through, probably during the process of dispersion and loan) does not affect significantly the survival of the resident population, and that the capture and tagging method does not affect the subsequent probabilities of recapture significantly. Both two assumptions were evaluated using the U-Care program (Choquet et al. 2003) which, in contrast to other commonly used programs such as RELEASE (Burham et al. 1987), employs algorithms designed to situations with moderate quantities of data, as this study. The population size was calculated as the ratio between the number of individuals captured and the probability of capture, as estimated using the CJS model (Lindenmayer et al. 1998). The proportion of males and females was expressed as the number of males for each female. The deviation of this proportion vis-à-vis a 1:1 ratio was analyzed using binomial coefficients test (Zar 1999). The average length of stay, defined as the number of months of observed or inferred presence, was compared between males and females using the Mann-Whitney U-test.

The linear distance was calculated between successive capture sites for each individual, and the monthly averages were compared between males and females using the non-parametric Wilcoxon test. As an additional measurement of movement, recapture frequencies in the same trees where specimens were captured were compared with the number of recaptures in different trees for both males and females using a $2 \times 2$ contingency table.

\section{RESULTS}

From January to June of 2007 a sample effort was undertaken involving 455 trapnights, allowing 159 captures and recaptures, a collection success rate of $18.92 \%$. A total of 36 individuals were captured, of which half of them were captured in low canopy and seven were juveniles. Due to the small sample size of this population stratum, the analysis of population and movement-based characteristics was carried out in relation to the adult specimens only. The sampling was comprised of 12 females and 17 males, with a total of 132 captures and recaptures which represents a collection success rate of $15.71 \%$. Whereas the males remained in the study area for an average of 3.58 months ( $\mathrm{SD}=2.31$ ), the females did so for an average of 2.5 (SD $=2.39$ ), though these differences were not statistically significant (Mann-Whitney Utest $=65, \mathrm{P}=0.101)$. The maximum length of stay was seven months; this was observed or inferred in relation to two males and two females. Additionally, eight females and five males were captured on just one occasion. 
Non statistically significant effect was observed in transitory individuals (males $=1.4646, \mathrm{P}=0.14303$; females $=1.0588 ; \mathrm{P}=0.28969$ ); nor was a statistically significant effect observed in the collection or tagging methods (males $=-0.86312$, $\mathrm{P}=0.38807$; females $=0, \mathrm{P}=1$ ). The best candidate model was the one in which the probability of survival remained constant through time, and was the same for both sexes; likewise, it was the one whose probability of capture was also constant through time, though differed between the sexes $\left(\phi, p_{s}\right)$ (Table 1). The model's observed deviance was 73.113 with eight freedom degrees and an overdispersion of 9.139. Of the 1,000 replications, 95 showed more deviances than those observed in the model; thus, it could be concluded that the extrabinomial variation in the capture-recapture histories is not statistically significant $(\mathrm{P}=0.098)$. On the other hand, the average overdispersion of the simulation replications was 6.640 , reason for which the parameters of all the models were adjusted to 1.3764 , which is the relationship between the observed overdispersion and the simulation average. Once the parameters were adjusted, the $\left(\phi, p_{s}\right)$ model continued being the best as it explains better the variations in the capture-recapture histories, outperforming the second best model $(\phi, p)$ by $207.7 \%$. The probability of survival of adult $N$. sumichrasti throughout the seven-month study in El Mameyal was 0.8287 and the probability of male capture was $30 \%$ higher than the probability of female capture (Table 2). The estimated adult population size was 40 individuals: 19 males and 21 females, which does not differ significantly from the ratio of $1: 1(Z=0.1583$, $\mathrm{P}=0.8742$ ).

Whereas the adult female average distance travelled was $34.86 \mathrm{~m}(\mathrm{SD}=5.92$, extremes 20.1-60.32 m), the adult male average distance was $35.42 \mathrm{~m}(\mathrm{SD}=18.27$ $\mathrm{m}$, extremes 10.3-75.1 m), though the differences were not statistically significant (Wilcoxon, corrected for ties, $\mathrm{Z}=-0.0848, \mathrm{P}=0.9324$ ) the average value for the entire population was $35.21 \mathrm{~m}(\mathrm{SD}=16.91)$. In contrast, the females were recaptured with significantly greater frequency in the same tree in which they had been captured $(85.71 \%)$ than were the males $(63.15 \%)($ Chi-square $=5.081, \mathrm{P}=0.0241)$.

\section{DISCUSSION}

The difference in the probability of capture between the males and females can be explained because although the average distances traveled do not differ significantly, when movement is measured as the number of recaptures in trees different from those of capture, the males show significantly higher values. This greater mobility among males has been documented in other rodent species and may be attributed to the active search for females (Santos-Moreno et al. 2007).

Fleming (1970) estimated the population size of $N$. sumichrasti in the area of the Panama Canal as being comprised of two (in June) and fifteen (in January). In 
Table 1. Description of 16 candidate models used to explain the patterns of variation in the capturerecapture histories of Nyctomys sumichrasti. $\phi=$ probability of survival; $p=$ probability of capture; $\mathrm{QAICc}=$ corrected Quasi-likelihood Akaike Information Criterion; $\delta \mathrm{QAICc}=$ difference between the respective QAICc model and the saturated model; QAICc weight = relative contribution of the QAICc of the respective models vis-à-vis the QAICc of the entire set of models.

\begin{tabular}{|c|c|c|c|c|c|c|}
\hline & & & & Model & Number of & \\
\hline Model & QAICc & $\delta$ QAICc & QAICc Weight & Likelihood & Parameters & QDeviance \\
\hline$\Phi, p_{s}$ & 93.993 & 0 & 0.38558 & 1 & 3 & 53.119 \\
\hline$\Phi, p$ & 95.455 & 1.461 & 0.18564 & 0.4815 & 2 & 56.765 \\
\hline$\Phi_{s}, p_{s}$ & 95.764 & 1.770 & 0.15911 & 0.4126 & 4 & 52.637 \\
\hline$\Phi_{s} p$ & 97.626 & 3.632 & 0.06271 & 0.1626 & 3 & 56.751 \\
\hline$\Phi_{t}, p_{s}$ & 100.732 & 6.738 & 0.01327 & 0.0344 & 8 & 47.860 \\
\hline$\Phi_{t} p$ & 101.999 & 8.005 & 0.00704 & 0.0183 & 7 & 51.681 \\
\hline$\Phi p_{t}$ & 106.519 & 12.52 & 0.00073 & 0.0019 & 7 & 56.202 \\
\hline$\Phi_{s} p_{t}$ & 109.060 & 15.066 & 0.00021 & 0.0005 & 8 & 56.188 \\
\hline$\Phi_{t}, p_{t}$ & 112.258 & 18.264 & 0.00004 & 0.0001 & 11 & 51.195 \\
\hline$\Phi, p_{s \cdot t}$ & 114.607 & 20.613 & 0.00001 & 0 & 13 & 47.596 \\
\hline$\Phi_{s * r} p_{s}$ & 116.370 & 22.376 & 0.00001 & 0 & 14 & 46.222 \\
\hline$\Phi_{s \bullet t} p$ & 116.415 & 22.421 & 0.00001 & 0 & 13 & 49.404 \\
\hline$\Phi_{s} p_{s * t}$ & 117.650 & 23.656 & 0 & 0 & 14 & 47.503 \\
\hline$\Phi_{t} p_{s * t}$ & 122.202 & 28.208 & 0 & 0 & 17 & 41.921 \\
\hline$\Phi_{s * p} p_{t}$ & 129.179 & 35.185 & 0 & 0 & 17 & 48.899 \\
\hline$\Phi_{s \bullet t} p_{s \cdot t}$ & 140.296 & 46.30 & 0 & 0 & 22 & 40.254 \\
\hline
\end{tabular}

comparison, the estimations obtained in El Mameyal seem high (Table 2); this may be due to at least in part the fact that, although Fleming (1970) also utilized capturerecapture methods, the estimate of the population size was obtained with an enumeration method similar to the Minimum Number Known Alive (Krebs 1966), which, unlike probabilistic models, underestimates this parameter (Nichols \& Pollock 1983, Menkens \& Anderson 1988, Santos-Moreno et al. 2007). 
Table 2. Probability of survival $(\phi)$, probability of capture $(p)$, sample size $(n)$, and estimate of the adult population size $(N)$ of Nyctomys sumichrasti according to the model $\phi, p_{s}$.

\begin{tabular}{ccc}
\hline Parameter & Estimate & Standard Error \\
\hline$\phi$ & 0.8287 & 0.0547 \\
$P_{\text {Males }}$ & 0.8740 & 0.0691 \\
$P_{\text {Female }}$ & 0.5733 & 0.1454 \\
$n_{\text {Males }}$ & 17 & - \\
$n_{\text {Females }}$ & 12 & - \\
$N_{\text {Males }}$ & 19 & - \\
$N_{\text {Females }}$ & 21 & - \\
\hline
\end{tabular}

As for the age structure, and in contrast to the observed difference in El Mameyal, where juvenile specimens were not very abundant, in Nicaragua the five recognized age categories were represented in equal proportions in the population (Genoways \& Jones 1972). These authors proposed that this pattern of a high proportion of juveniles and sub-adults is probably due to the high survival rates because the dense vegetation of the area minimizes the probability of depredation. In the population of El Mameyal, juveniles and sub-adults represented only $19.4 \%$ of the captured individuals and although the sample size does not allow us to estimate the survival rate of the age stratum, its low presence in the sampling probably reflects precisely this (i.e., a low survival rate). The study area's vegetation shows evidence of having experienced considerable impact mainly due to logging; thus, the canopy is not very dense. These results appear to confirm the hypothesis that the vegetation cover is a factor that influences the depredation rate of $N$. sumichrasti, particularly towards juveniles, as their ability to detect and avoid predators is lower than that of adults (Webster \& Webster 1971, Dickman et al. 1991); moreover, adults generally occupy safer spaces with dense vegetation, where the risk of falling prey to raptors is lower than in open areas (Koivunen et al. 1996). The male-female ratio of 1:1 observed in El Mameyal was observed in Nicaragua as well (Genoways \& Jones 1972).

Pattern of movements match with previous observations of $N$. sumichrasti in Mexico, indicating that this species is strictly tree-dwelling, though samples in northeastern Nicaragua were collected on the ground at the base of trees (Genoways \& Jones 1972). Whereas other studies documented captures at heights between 0.7 and 3 m (Lawlor 1969, Collett et al. 1975, Ceballos 1990, Sánchez-Hernández et al. 1999), more than 46\% of the captures in El Mameyal were between 9 and $21 \mathrm{~m}$. There are at least two factors that may be able to explain these differences: the fact that in this study the traps were set by climbing the trees with ropes which allowed 
access to much higher locations than those accessible by ladder, the most common method employed in other studies. On the other hand, it is likely that vertical stratification depends on the number of species of which the community is comprised. For example, in Nicaragua, $N$. sumichrasti was observed co-existing with at least thirteen other species of small mammals and, as proposed, this may be due to the use of the third dimension (arboreal); that is, the movement of $N$. sumichrasti appears to be restricted, specifically, to lower strata vegetation usually heights of 10 to 20 feet (Genoways \& Jones 1972). In contrast, in another part of Nicaragua where $N$. sumichrasti is found in the same habitat only with Ototylomys phyllotis (its closest ecological counterpart), $N$. sumichrasti is restricted to the higher tree levels, at heights usually greater than 10 feet, while $O$. phyllotis usually forages on lianas and branches below the area of activity of $N$. sumichrasti (Lawlor 1969). In El Mameyal, $N$. sumichrasti was captured in trees along with Reithrodontomys sumichrasti, Peromyscus aztecus, Marmosa mexicana, and Tylomys nudicaudus, but only the first one of these species was abundant; in fact, it proved to be the most abundant of species throughout the study. Demonstrating a competitive interaction between $N$. sumichrasti and $R$. sumichrasti, as well as demonstrating the effects of vertical stratification, would require further studies.

Some studies undertaken in communities with temperate climates indicate that vertical stratification as a mechanism that facilitates the co-existence of various species is not exclusive of tropical regions. For example, in syntopic areas of the Peromyscus maniculatus and P. leucopus inter-specific competition is reduced, allowing the coexistence of both species (Smith \& Speller 1970, Meserve 1977, Barry et al. 1984).

Whereas Fleming (1970) in Panama observed that an adult male N. sumichrasti traveled an average distance 1.5 times greater than that of two females $(68.5 \mathrm{~m}$ and $45.2 \mathrm{~m}$, respectively), in El Mameyal the distances traveled by both males and females were statistically equal, these differences could be attributed to the small sample size from which Fleming (1970) obtained his estimates. The value of 35.21 $\mathrm{m}$ as an average distance traveled by adult $N$. sumichrasti is probably an underestimate, as estimations obtained from trapping are usually smaller than those obtained with more precise techniques, such as radio-telemetry (Sáenz 1999, Ribble et al. 2002). Although the movements of very few species with tree-dwelling or semitree-dwelling habits have been studied, the observed values of adult $N$. sumichrasti are similar to those observed in other rodent species of similar size and habits in tropical and subtropical environments, such as Xenomys nelsoni, though in relation to this last species, the males have been shown to travel double the distance of females (Ceballos 1989), and Peromyscus perfulvus, whose males and females were shown to travel a maximum distance of $67 \mathrm{~m}$ and $36 \mathrm{~m}$, respectively (Schnell et al. 2008). 
ACKNOWLEDGMENTS. This project was financial supporting by Instituto Politécnico Nacional of Mexico (grants SIP-20070826 and SIP-20080431 to A. Santos-M.). The authors would also like to thank the local (municipal) authorities of Santiago Comaltepec for the available facilities. A. Alfaro E. revised preliminary versions of this document, and J. L. García-García and A. E. Hernández Cruz provided invaluable field support. Silvia Hernández B. and an anonymous reviewer provided valuable suggestions and comments.

\section{LITERATURE CITED}

Anthony, H.E. 1932. A new genus of rodents from Yucatan. American Museum Novitates, 586:1-3.

Barry, R.E., Jr., M.A: Botje \& L.B. Grantham. 1984. Vertical Stratification of Peromyscus leucopus and P. maniculatus in Southwestern Virginia. Journal of Mammalogy, 65:145-148.

Birkenholtz, D.E. \& W.O. Wirtz. 1965. Laboratory observations on the vesper rat. Journal of Mammalogy, 46:181-189.

Boyle, B.L. 1996. Changes on altitudinal and latitudinal gradients in Neotropical montane forest. $\mathrm{Ph}$. D. Thesis. Washington University. USA.

Burnham, K.P., D.R. Anderson, G.C. White, C. Brownie \& K.H. Pollock. 1987. Design and analysis methods for fish survival experiments based on release-recapture. American Fisheries Society Monographs, 5:1-436.

Burnham, K.P. \& D.R. Anderson. 2002. Model selection and inference -A practical informationtheoretic approach. Springer-Verlag, New York.

Ceballos, G. 1989. Population and community ecology of small mammals in a tropical deciduous forest in western Mexico. Ph. D. Thesis, University of Arizona, Tucson, USA.

Ceballos, G. 1990. Comparative natural history of small mammals from tropical forests in western Mexico. Journal of Mammalogy, 71 263-266.

Choquet, R., A.M. Reboulet, R. Pradel, O. Gimenez \& J.D. Lebreton. 2003. User's manual for UCare, Utilities-CApture-REcapture, V2.02, CEFE/CNRS, Montpellier (ftp://ftp.cefe.cnrs.fr/ biom/U-CARE).

Collett, S.F., C. Sanchez, K.A. Shum, Jr., W.R. Teska \& R.H. Baker. 1975. Algunas características poblacionales demográficas de pequeños mamíferos en dos hábitats mexicanos. Anales del Instituto de Biología, Universidad Nacional Autónoma de México, Serie Zoología, 1:101-124.

Cooch, E. \& G. White. 2002. Program MARK. Analysis of data from marked individuals. A gentle introduction. 2d. ed. Ithaca, New York.

Cormack, R.M. 1964. Estimates of survival from the sighting of marked animals. Biometrika, 51:429438.

Dickman, C.R., M. Predavec \& A. J. Lynam. 1991. Differential predation of size and sex classes of mice by the barn owl, Tyto alba. Oikos, 62:67-76.

Disney, R.H.L. 1968. Observations on a zoonosis: leishmaniasis in British Honduras. The Journal of Applied Ecology, 5:1-59.

Emmons, L.E. 1999. Neotropical rainforest mammals. 2d. ed. The University of Chicago Press, Chicago.

Fleming, T.H. 1970. Notes on the rodent faunas of two Panamanian forests. Journal of Mammalogy, 51:473-490.

García García, J.L. 2007. Estructura poblacional del murciélago Dermanura tolteca (Saussure, 1860) en el Municipio de Santiago Comaltepec, Oaxaca. M. Sc. Thesis, Instituto Politécnico Nacional de México, Oaxaca, México.

Genoways, H. \& J.K. Jones, Jr. 1972. Variation and ecology in a local population of the vesper mouse (Nyctomys sumichrasti). Occasional Papers of the Museum, Texas Tech University, 9:1-22. 
Goodwin, G.G. 1934. Mammals collected by A.W. Anthony in Guatemala, 1924-1928. Bulletin of the American Museum of Natural History, 68:1-60.

Goodwin, G.G. 1969. Mammals from the state of Oaxaca, Mexico, in the American Museum of Natural History. Bulletin of the American Museum of Natural History, 141:1-269.

Hall, E.R. 1981. The mammals of North America. Vol. 1 and II. John Wiley and Sons, New York

Jolly, G.M. 1965. Explicit estimates from capture-recapture data with both death and immigrationstochastic model. Biometrika, 52:225-247.

Koivunen, V., E. Korpimaki \& H. Hakkarainen. 1996. Differential avian predation on sex and size classes of small mammals: doomed surplus or dominant individuals?. Annales Zoologici Fennici, 33:293-301.

Krebs, C.J. 1966. Demographic changes in fluctuating populations of Microtus californicus. Ecological Monographs, 36:239-73.

Lawlor, T.E. 1969. A systematic study of the rodent genus Ototylomys. Journal of Mammalogy, 50:2842.

Lebreton, J.-D., K.P. Burnham, J. Clobert \& D.R. Anderson. 1992. Modeling survival and testing biological hypotheses using marked animals: a unified approach with case studies. Ecological Monographs, 62:67-118.

Lindenmayer, D.B., R.C. Lacy \& K.L. Viggers. 1998. Modeling survival and capture probabilities of the mountain brushtail possum (Trichosurus caninus) in the forests of southeastern Australia using trap-recapture data. Journal of Zoology, 245:1-13.

Malcolm, J.R. 2004. Ecology and conservation of canopy mammals. Pp. 297-331. In: M.D. Lowman, N.M. Nadkarni and H.B. Rinker (Eds.). Forest canopies. 2nd. ed. Academic Press, New York:

Manly, B.F.J. 1997. Randomization, bootstrap and Monte Carlo methods in biology. 2d. ed. Chapman \& Hall/CRC, New York.

Menkens, G.E., Jr. \& S.H. Anderson. 1988. Estimation of small mammal population size. Ecology, 69:1952-1959.

Meserve, P.L. 1977. Three-dimensional home ranges of cricetid rodents. Journal of Mammalogy. 58:549-558.

Musser, G.G. \& M.D. Carleton. 2005. Super family Muroidea. Pp. 894-1531. In: D.E. Wilson.and D.M. Reeder (Eds.). Mammal Species of the World. Johns Hopkins University Press, Baltimore.

Nichols, J.D. \& K.H. Pollock. 1983. Estimation methodology in contemporary small mammal capturerecapture studies. Journal of Mammalogy, 64:256-261.

Peña, L.A., Y. Domínguez \& B. Hernández. 2005. Nyctomys sumichrasti (Saussure, 1860). Pp. 701702. In: G. Ceballos and G. Oliva (Eds.). Los mamíferos silvestres de México. Fondo de Cultura Económica and Comisión Nacional para el Conocimiento y Uso de la Biodiversidad. México, D. F.

Ribble, D.O., A.E. Wurtz, E.K. Mcconnell, J.J. Buegge \& K.C. Welch, Jr. 2002. A comparison of home ranges of two species of Peromyscus using trapping and radiotelemetry data. Journal of Mammalogy, 83:260-266.

Sáenz, J.C. 1999. Movimientos y selección de microhabitat de una rata arborícola Ototylomys phyllotis (Rodentia: Muridae) en un bosque seco tropical. Brenesia, 52:61-64.

Sánchez-Hernández, C., M.L. Roméro-Almaraz, R.D. Owen, A. Núñez-Garduño \& R. LópezWilchis. 1999. Noteworthy records of mammals from Michoacán, Mexico. The Southwestern Naturalist, 44:231-235.

Santos-Moreno, A., M.A. Briones-Salas \& R. López-Wilchis. 2007. Diferencias en algunos parámetros demográficos de Oryzomys chapmani (Rodentia: Muridae) asociadas a tres estados sucesionales de bosque mesófilo de montaña en Oaxaca, México. Acta Zoológica Mexicana (nueva serie), 23:123-137. 
Schnell, G.D., M.L. Kennedy, C. Sánchez-Hernández, M.L. Romero-Almaraz, B.D.N. Estevez, J. A. Guerrero, T.L. Best, M.C. Wooten \& R.D. Owen. 2008. Habitat preference of the endemic tawny deermouse (Peromyscus perfulvus), a species of conservation concern. The Southwestern Naturalist, 53:9-20.

Seber, G.A.F. 1965. A note in multiple recapture census. Biometrika, 52:249-259.

Seber, G.A.F. 1982. The estimation of animal abundance and related parameters. Charles Griffin \& Co., London.

Seber, G.A.F. 1986. A review of estimating animal abundance. Biometrics, 42:267-292.

Secretaría de Medio Ambiente Recursos Naturales y Pesca (SEMARNAP), Instituto Nacional de Estadística, Geografía e Informática (INEGI) \& Instituto de Geografía, Universidad Nacional Autónoma de México (UNAM). 2000. Inventario Forestal Nacional 2000-2001. Escala 1:250000. Instituto de Geografía, UNAM, México.

Smith, D.A. \& S.W. Speller. 1970. The distribution and behaviour of Peromyscus maniculatus gracilis and Peromyscus leucopus noveboracensis (Rodentia: Cricetidae) in a southeastern Ontario woodlot. Canadian Journal of Zoology, 48:1187-1199.

Timm, R.M. \& C. Vriesendorp. 2003. Observations on feeding behavior in the vesper mouse, Nyctomys sumichrasti. Mammalian Biology, 68:126-128.

Webster, D.B. \& M. Webster. 1971. Adaptive value of hearing and vision in kangaroo rat predator avoidance. Brain, Behavior and Evolution, 4:310-22.

Woodman, N., N.A. Slade, R.M. Timm \& C.A. Schmidt. 1995. Mammalian community structure in lowland, tropical Peru, as determined by removal trapping. Zoological Journal of the Linnean Society, 113:1-20.

Zar, H.H. 1999. Biostatistical analysis. $4^{\text {a }}$. ed. Prentice Hall, Upper Saddle River, New Jersey. 